\title{
Young people's attitudes towards Muslims in Sweden
}

\author{
Pieter Bevelander \& Jonas Otterbeck ${ }^{1}$
}

First draft, not to be quoted without permission of authors

\begin{abstract}
Since the 1950's, the Muslim population in Sweden has grown from just a few individuals to approximately 350,000 of which one third is of school age or younger. With the use of multiple regression technique, the principal objective has been to clarify and examine young people's attitudes towards Muslims, and the relationships between these attitudes and a large number of background factors. The material employed in the analysis comprises a representative sample of 9,498 non-Muslim youths (4,680 girls and 4,818 boys) between 15-19 years of age. The main results of the study show that when controlling for several background variables simultaneously that many variables affect the attitude towards Muslims. Country of birth, socio-economic background and school/program factors are found to have an effect on the attitude towards Muslims. Moreover, especially social psychological factors, friend factors and perceptions on gender role patterns are found to be important. Besides, local/regional factors like increased unemployment, higher share immigrants in local environment also have an effect on the attitude towards Muslims. Finally, no difference in the attitude of boys and girls were measured.
\end{abstract}

Prepared for Fourth IZA Annual Migration Meeting (AM²) Bonn, IZA May 21/22, 2007

\footnotetext{
${ }^{1}$ Pieter Bevelander is Assoc. Prof. and researcher at MIM, Malmö Institute of Migration, Diversity and Welfare, IMER, Malmö University, Sweden and Research fellow at IZA, Bonn, Germany. Jonas Otterbeck is lecturer and researcher at IMER, Malmö University, Sweden. The research for this paper has been financed by the Living History Forum, Sweden. For our first report, in Swedish, see Otterbeck \& Bevelander 2006.
} 


\section{Introduction}

The Swedish Muslim population has increased dramatically during the last quarter of the $20^{\text {th }}$ century. Although we have no exact statistical records by religion in Sweden, the number of individuals with a Muslim background has increased from just a couple of families in the 1950s, via approximately 100,000 at the end of 1980s, around 200,000 in 1996, to approximately 350,000 individuals in 2000. The majority of the Muslims in Sweden has gained access as refugees or as family to refugees, only a small part as labour migrants. In Sweden we find Muslims with roots in for example: Turkey, the Balkan, Eastern Mediterranean, North-Africa, East-Africa, West-Africa, Iran, Iraq, Afghanistan, Pakistan, Southeast-Asia, Central-Asia, Finland and the Baltic. There is also an increasing Swedish born Muslim population since many young Muslims who have immigrated to Sweden raise families. Approximately one third of the Muslim population is in school ages or younger (Anwar, Blaschke \& Sander 2004).

To integrate into another society, economically, socially, politically and culturally takes time. Also to evaluate and translate home country educational credentials and labour market experience can be a long process. For some of the Muslim groups this integration has gone better than for others. Bosnians, generally having a Muslim background, is one of the immigrant groups in Sweden with highest labour market attachment despite the relatively short stay in the country. For immigrants from Iraq, on the contrary, we find strikingly low employment integration (Bevelander \& Lundh 2007).

Religious belonging is one of the central factors for the formation of social relations and communities even in a strongly secularized Swedish society. To be religious different can create barriers and aggravate daily life and can lead to lower chances in the housing- and labour market. Sometimes even structures in laws, educational systems and other societal sectors, for example; religious rules on slaughter of animals, religious education, uniform, etc, cause religious minorities to get into difficult situations. At the same time the Swedish society slowly adapt to the demographic changes in an ongoing process. 
According to a number of research reports, youth in Sweden live in a media climate that is not particular sympathetic towards Islam. For example, the news, popular culture and textbooks are often being accused of superficial portrayals of Islam (Berg 1998; Hvitfelt 1998; Otterbeck 2006). In brief, when Islam is seen as something negative (which is not always the case) it is presented as a threat, uniform and homogenous, expanding, undemocratic, patriarchal and different. Analyzing TV-news during 1991-1995, Hvitfelt (1998) shows that while 25 percent of all news is connected to violence, this for news relating to Muslims and Islam is 85 percent. Observe that Muslims can both be depicted as perpetrator or victim. Naturally, these results have been affected by the fact that the period 1991-1995 was a turbulent period in several Muslim societies with many violent developments - this also holds for the period during which the data for this study was collected, namely 2003. TV-news focus heavily on negative and crisis like events. But regardless of the many actual conflicts, the TV-news discourse created on Muslims and Islam is to a high degree connected with violence and conflict.

In popular culture, the stereotypes of Muslims are gender specific. Males are active in a negative way, engaged in violence and the oppression of women, they are treacherous and self-righteous, while women are suppressed and are seen as a collective without freedom of action. These images of Muslims can often be found in movies, novels, cartoons, computer games, etc (Berg 1998).

Studies on textbooks show how representations of Islam changes over time and especially how these changes can be explained by changes in the society the authors of textbooks live in (Härenstam 1993; Otterbeck 2006). But despite the increase in number of Muslim youth in primary and secondary education, still a so called "we (Swedish, Christian) and them (Muslims)-perspective" dominates many textbooks in the subject of religion (Otterbeck 2006).

If searching on the internet for Islam critical voices one does not have to become disappointed. Besides many striking attacks on Islam and Muslims in discussion sites of leading newspapers, there are more systematically Islam hostile homepages from right wing populist parties (National Democrats and Swedish Democrats) as well as from many smaller organizations and private pages (Lagerlöf 2006). Most of these homepages mediate the view that Muslims don't want to integrate in Swedish society and that 
Muslims and Islam have come to take over Sweden or "Swedishness" and want to dominate Sweden and convert Swedes to Islam. So, Muslims should leave the country or even be exterminated.

Even if we in the above mix results and take away nuances, the main is that the information on Muslims and Islam that is mediated to youth in Sweden through different channels is more or less stereotypical and often has a negative connotation.

Swedish studies on the attitudes on Muslims and Islam are all but one on adult individuals. The only study that has focused on attitudes on Muslims by young people is presented in a report (Intolerans 2004) commissioned by the Forum for Living History and the Crime Preventing Board in Sweden. Contrary to earlier studies on attitudes on Muslims and Islam for adults, this study showed a relatively high tolerance for Muslims. Further, this study showed that many different factors could be related to either a higher or lower tolerant attitude towards Muslims. However, like earlier studies this study did not make use of more sophisticated statistical methods.

The above discussed societal factors, an increasing population with a Muslim background and the relatively slow integration process of many Muslim groups, a relatively negative media climate on Muslims and Islam, as well as that relatively few studies have been undertaken on this subject, makes studies on the attitudes of the majority on the Muslim minority of great importance. Young people, both non-Muslim and Muslim, are going to be the workers and employers, politicians, etc in the future and their attitudes towards Muslims and the determinants behind these attitudes is therefore of even greater importance. The main aim of this paper is thus to study the attitudes of non-Muslim youth on Muslims in Sweden. Furthermore, since few studies have been conducted in a more explorative way, this study will explore to what extend these attitudes could be explained by a number of background factors (a) demographic factors, (b) socio-economic factors, (c) local/regional factors, (d) school factors, (e) psychosocial factors, (f) parental factors, (g) friend factors, (h) isolation factors and (i) gender factors. 
The next section of the paper tracks earlier studies and their results as well as elaborate on different explanations for differences in attitudinal behaviour. The succeeding section describes the data, methods and variables used for our analysis. The results are then presented, followed by a concluding discussion.

\section{Theory and earlier research}

There are a number of theoretical propositions that have been brought forward to explain the mechanisms behind negative or positive attitudes towards others and more extreme variations of this like xenophobia, racism and Islamophobia. In the following we give a short overview of these theoretical concepts which partly stem from either the individual level, a family or group level or at the societal level. This is followed by an account of some studies with focus on attitudes towards Muslims.

One of the most well known studies focusing on individual prerequisites and characteristics is Adorno et al. (1950). This study connects the so called authoritarian personality to anti-democratic behaviour combined with anti-Semitism, ethnocentrism, etc. A modern variation of this theoretical proposition was used by the socialpsychologist Tajfel who developed the so called social identity theory (Tajfel 1982). This theory presents the idea that ethnocentrism, negative attitudes and discrimination is based on the tendency individuals have to categorize themselves in so called "in" and "out" groups. This in turn depends on a deeper need to get or uphold status which can be achieved by comparing "in"- and "out" groups. The more an individual identifies with his/her "in" group, the stronger negative attitude he/she will have against an "out" group. At the same time, this theory does not explain divergence in attitudes between different immigrant and ethnic groups. Neither does it explain why certain individuals systematically have a high negative attitude than others. A more sociological explanatory concept is the so called realistic conflict theory which stresses real conflicts of interests between groups and competition for scarce resources like education, employment and housing (Sherif 1966). A development of this theory is the so called power-threathypothesis. According to this, a negative attitude towards certain groups is due to that these groups are seen as economic competitors and challenge the social and political 
power of another (Blalock 1967). A more socio-ecological variation emphasizes the environment individuals live in and is more or less a variation of the power-threathypothesis. A feeling of threat increases with immigration of new groups. These groups become more visible which diminishes the social distance to the majority. Another variant on this is called defended neighbourhoods theory which states that a fear of losing ones identity increases with a faster pace of change in neighbourhood composition (Dustmann, Fabbri \& Preston 2004). Finally, and in contrast to the rather negative focus of Dustmann et al. (2004), according to Allport's contact hypothesis attitudes towards other groups are more positive when contacts between groups increase, especially when individuals have the same socio-economic background and try to obtain the same goals (Allport 1958).

Some theories concentrate on the development of tolerance in adolescence and concentrate on the personal development of the individual. Robinson et al. (2001) stress the importance of socialisation and especially parental practices (not only verbal tolerance) and education for the development of a tolerant mind. Young adolescents seem to be more intolerant towards those holding opposing beliefs while older adolescents tend to be more tolerant and understanding towards those of opposite beliefs. The growth of tolerance correlates strongly with Piaget's cognitive stages according to Robinson et al (2001). At the same time individuals are not either tolerant or intolerant, both attitudes coexist in all individuals. Tolerance is situational.

Another set of theories is based on a more structural understanding of prejudices and racism. The theories attempt to uncover how economic, political and social power over states and institutions (re)produce discursive orders, benefits and resources along ethnic, racial, cultural, religious or other lines, securing the power position of the elite. These theories often focus on how cultures (and religions) are essentialised, seen as separate from each other and how they are finally ordered in hierarchies (Fredrickson 2003). A common trait is that theories on racism today often stress the focus put on culture, rather than race, and how culture is made the functional equivalent of race in the sense that it becomes inherent in the individual classified as belonging to a specific culture (Balibar 1997/2002; Solomos \& Back 1999:20). These orders, at times invisible but always present, saturate public discourse and are manifested in stereotypes, jokes, 
popular culture but also in laws, politics, and discrimination on the labour and housing market. The orders often have long histories and are in the West European and North American case more often than not interconnected to the colonial period. Thus, while the studies above focus on interpersonal relations, these theories focus on discourses and power relations with a long history and that are well spread.

Earlier research on attitudes towards Islam and Muslims in Sweden is primarily on the adult population. The first study of Swedes' attitudes towards Islam and Muslims was done in 1990 by Hvitfelt (1991) and the result of this study was that almost 65 percent of the Swedish population was fairly to very negative towards Islam. 88 percent was of the opinion that the Islamic religion was incompatible with the Swedish democratic system and 62 percent had the view that the religion led to female repression. Finally this study showed that almost 75 percent where against the building of mosques in Sweden and 75 percent were of the opinion that the immigration of Muslims should be reduced. It should be noticed that this study was performed in connection with a period, the late 1980s, in which the non-European immigration to Sweden had increased dramatically which certainly affected the discussion about Muslims in Sweden. One example of this is how certain members of the new right wing populist political party, New Democrats (Ny Demokrati), depicted the increase in number of Muslims as a threat against Swedish culture and prosperity.

Later studies on the attitudes to Muslims and Islam are mainly commissioned by the Swedish Integration Board (Integrationsverket). An example of this is the report "Dialogue with Swedish Muslims" (Samtal med svenska muslimer 2003) which has the aim to study how Muslims experienced their situation the immediate period after September 11, 2001. The study claims that the respondents felt a more negative climate against Islam and Muslims, but also an increasing interest around the Islamic religion in general. Since we don't have earlier studies, it is difficult to say if a more negative climate really occurred, nor is it possible to say if a possible negative effect was permanent or just temporal. Further, Åslund and Rooth (2005) analyzed the effect of September 11 on the probability to leave unemployment by immigrants with a Muslim 
background. Contrary to what was expected by the result of the attitudinal studies discussed earlier, they found no increase in discrimination.

Other attitudinal studies commissioned by the Integration Board, The Integration Barometer (2005 and 2006), studied the attitudes of the general public with the use of a couple of indicators. These studies show that the ones who have a more positive attitude towards Muslims and Islam are women more than men, individuals living in large cities more than individuals living in smaller cities and the country site, and those with higher educated more than the ones with lower educated. In the latter study also an age effect was measured; the younger the respondents were, the more positive towards Muslims and Islam.

The results of the Swedish studies on attitudes are largely in line with those found in other European countries like Germany and Switzerland. Heitmeyer (2002, 2003, 2004 and 2005) found for Germany that men had a less positive attitude towards Muslims than women. Furthermore, a more negative attitude was measured with increased age and a more positive with increased education. Political affiliation showed that individuals more to the right had less positive attitude than those more to the left, who were more positive. Higher levels of unemployment and a larger share of immigrants living in the different states were correlated with a less positive attitude towards Muslims. In the latest study a difference between "east" and "west" Germany is observed, with a more negative attitude towards Muslims by people living in "west". Furthermore, these studies show that individuals that are more affected by so called social dominance, e.g. the feeling that ones existence is becoming less secure by the settlement of others, are less positive to Muslims. Finally, individuals with authoritarian perceptions are also slightly less tolerant to Muslims than others. For Switzerland, Cattacin et al. (2006) found that approximately 30 percent of the population had Islamophobic attitudes, which is slightly higher than for Germany (20-25 percent). Moreover, Cattacin's study found little correlation between Islamophobia and racism, xenophobia and anti-Semitism.

Using the same questionnaire as our study, the Intolerance report (Intolerans 2004) tried to measure the attitudes of young people in Sweden towards Muslims, Jews, homosexuals and immigrants. Contrary to earlier studies and certainly compared to the study 
performed in 1990, this study showed that young people were rather tolerant. Only 5 percent are intolerant, out of which 1.7 percent is extremely intolerant. When it comes to attitudes towards Muslims, 8 percent are intolerant. Moreover, this study also tried to link a number of background factors with a so called intolerance measure in this study. The results of these cross tabulations are that individuals with higher intolerance towards Muslims are for example: boys, youth having parents with lower socio-economic background, youngsters that are enrolled in lower level educational programs, young people living in country site and those born in Sweden.

\section{Data, model and method}

In this study we analyze the attitudes towards Muslims by young non-Muslims in Sweden. The data used is based on classroom questionnaire performed during month of December 2003 among pupils in the two highest levels of primary school and the three following levels at gymnasium. The pupils are between the ages 15-19. ${ }^{2}$ The basic material comprises of a representative sample of 10,599 individuals which makes up approximately 2 percent of the total population in these age categories in Sweden. Of these, 565 individuals have indicated that they are Muslims and are therefore excluded from the analyses. An internal reduction of 536 individuals who have not answered all questions used in the analysis, does that the material for our analysis comprises 9,498 individuals, 5,680 girls and 4,818 boys. $^{3}$

The dependent variable in this study is a constructed attitudinal scale or index based on eight separate statements indicating a more positive or negative attitude towards Muslims. In appendix I theses separate statements are given as well as the mean values for girls and boys. The answering alternatives on these statements were: yes, this is correct; this is relatively correct; unsure/doesn't know; this is rather incorrect; no, this is incorrect. Since a large correlation in the answers between the statements could be

\footnotetext{
${ }^{2}$ The questionnaire was commissioned by the Crime Preventing Board (BR $)$ and the Forum for Living History.

${ }^{3}$ See Intolerans (2004) for more on the initial questionnaire, method of selection, etc.
} 
measured, an attitude index is made. ${ }^{4}$ The index is constructed so that an increasing level indicates a more positive attitude towards Muslims.

The independent variables, see appendix II for overview, are primarily based on the questions asked in the questionnaire. Some of these questions are dealing with demographic characteristics like age, gender and country of birth, whereas others are connected to the socio-economic background of the respondents. In this case the socioeconomic status of the parents, split in eight categories, was used, if the individual lives in a single-parent family or not and if one or both parents were unemployed were used as indicators for socioeconomic background. Local and regional factors are primarily based in which municipality an individual lives. Moreover, this variable is categorized in various ways to "catch" different aspects assumed to be connected to attitudes towards Muslims. This variable is categorized in type of municipality (appendix III), level of unemployment in municipality, share of foreign born population in municipality, the relative share of the manufacturing sector in the municipality and finally a dummy variable constructed on the basis of if a municipality had right wing populist mandates in local parliament or not. ${ }^{5}$ School factors like how comfortable the pupil is at school and the respondent's grade level are included as index variables. The kind of program the respondent is following, categorized in four levels, is also integrated in the model. This variable is assumed to catch the effect of socioeconomic background on the level of attitudes towards Muslims. These variables have certainly a strong connection to the socioeconomic background of the parents. Moreover, social psychosocial indicators are all index questions and constitute the following: aggressiveness, restlessness, risk preference and nervousness. These factors are assumed to measure the psychosocial behaviour on attitudes towards Muslims. Other indexes included in the model deal with parental factors which is assumed to measure contact between parents and adolescents. Friend factors are assumed to measure the influence of friends on behaviour. Also if the respondent has feelings of exclusion from society which

\footnotetext{
${ }^{4}$ The internal correlation is 0.90 measured as the Cronbach alfa coefficient which is on a satisfactory level. Since some of the statements where stated in the opposite direction, we reversed the coding for all statements in the same direction.

${ }^{5}$ The population and labour market indicators are based on data from Statistics Sweden. The political indicator is based on statistics of the local elections of 2002.
} 
is expected to measure societal belonging. Finally, gender role patterns are included and assumed to measure if attitudes towards gender role pattern are congruent with attitudes towards Muslims. The construction of all indexes and the questions asked can be found in appendix IV.

Many questions in the questionnaire that are included in the model are on an ordinal level and recoded to scales with the use of factor analysis. With the use of multiple regression technique, we estimate the effect of the various variables on the constructed index of attitudes towards Muslims. The model presented in the analysis includes all variables presented earlier as well as a separate analysis for girls and boys.

\section{Results}

The following result presentation starts with describing some selected results on both separate statements and the composed index based on our eight statements. After this we discuss the results of the multivariate analysis on the composed index.

\section{Descriptive analysis}

The attitudes towards Muslims has, as described earlier, been captured with eight separate statements were the answers have got numerical values from 0 to 4 . Appendix I shows the mean for the separate statements and where the respondents are split by a selection of background factors frequently found in the literature. A higher mean, close to 4, implicate a more positive attitude towards Muslims. The results show that some statements yield a more positive attitude than others. These statements are: "It would be entirely okay to have a steady Muslim as a neighbour" and "It should be forbidden for Muslims to vote in elections". Other questions, on the other hand, indicate clearly a more negative attitude towards Muslims. These are the statements: "There are far too many Muslims in Sweden" and "Most Muslims only want to live on social security". Generally the mean for boys is lower than for girls and have a somewhat more negative attitude towards Muslims. When it comes to differences between grades, the means indicate 
weakly a more positive attitude by pupils in the second and third grade in secondary education, in other words, the highest grades are more positive relative to lower grades. Finally, non-Swedish born, especially non-European born, have a slightly higher mean; i.e. a somewhat more positive attitude towards Muslims.

Table 1, Means for index, selected variables

\begin{tabular}{|c|c|c|}
\hline \multirow[t]{2}{*}{ Gender } & Girls & 2,91 \\
\hline & Boys & 2,56 \\
\hline \multirow[t]{5}{*}{ Grade } & Grade 8 (15 years old $)$ & 2,69 \\
\hline & Grade 9 (16 years old $)$ & 2,71 \\
\hline & Secondary 1 th grade & 2,69 \\
\hline & Secondary 2 th grade & 2,79 \\
\hline & Secondary 3 th grade & 2,86 \\
\hline \multirow[t]{4}{*}{ Program } & University preparing & 3,02 \\
\hline & University and professional preparing & 2,76 \\
\hline & Professional preparing & 2,49 \\
\hline & Individual & 1,77 \\
\hline \multirow[t]{4}{*}{ Region of birth } & Sweden & 2,72 \\
\hline & North/West/Eastern Europe & 2,76 \\
\hline & Southern Europe & 2,80 \\
\hline & Outside Europe & 2,84 \\
\hline \multirow[t]{8}{*}{ Parental socioeconomic background } & Non skilled worker & 2,47 \\
\hline & Skilled worker & 2,57 \\
\hline & Lower civil servant & 2,68 \\
\hline & Intermediate civil servant & 2,90 \\
\hline & Higher civil servant & 3,04 \\
\hline & Fri occupations with academic education & 3,13 \\
\hline & Entrepreneur & 2,71 \\
\hline & Agricultural worker & 2,70 \\
\hline \multirow[t]{8}{*}{ Municipality type } & Stockholm & 2,91 \\
\hline & Gothenburg & 2,80 \\
\hline & Malmoe & 2,73 \\
\hline & Other larger cities & 2,79 \\
\hline & Medium sized cities & 2,75 \\
\hline & Large municipalities & 2,58 \\
\hline & Smaller municipalities & 2,61 \\
\hline & Country site & 2,64 \\
\hline
\end{tabular}

In the following we analyse the results of the composed index on attitudes towards Muslims for selected background variables (see appendix IV). The calculated means for boys and girls show that boys have a somewhat less positive attitude towards Muslims 
which is in line with earlier reports. The index for age/grade show that increased age/grade is connected to a more positive attitude towards Muslims. Young people born in Sweden are, relatively those born abroad, less positive towards Muslims. Besides, youth born outside Europe are more positive than those born in Europe. When it comes to type of program, the analysis shows that those who attend university preparing levels have a more positive attitude towards Muslims and those who attend the individual level (lowest) have the least positive attitude towards Muslims. Moreover, the analysis shows differences in attitudes when the informants are split by socio-economic background of the parents. Youth whose parents have non-skilled or low skilled occupations, have a less positive attitudes towards Muslims. Especially, young people with parents that have academic occupations show a more positive attitude towards Muslims. The geographic division used in this study shows that respondents living in large cities, other major cities and medium sized cities have a more positive attitude towards Muslims than those who live in other regions. Moreover, those who live in Stockholm are more positive than those in Gothenburg who are in turn more positive than those in Malmoe.

In conclusion, the results of the descriptive analysis indicate that the attitude towards Muslims is different for various background factors. A more sophisticated method of understanding the effect of the above discussed variables and other characteristics on the attitude towards Muslims, is to regress these factors simultaneously.

\section{Multivariate analysis}

In the following table (table 2) the results of three regressions are presented which include all background variables. The first regression shows the results for both girls and boys. The other results are for girls and boys separately. The results indicate that some variables have no statistical significant effect on the attitude towards Muslims by young people, whereas other variables show either positive or negative effects. In the following we discuss the results by variable group.

Table 2, Adolescent attitudes towards Muslims, Multivariate regression.

\begin{tabular}{lllll}
\hline & All & & Girls & \multicolumn{1}{c}{ Boys } \\
\hline Boys & 0.034 & - & - \\
Grade 9 & -0.007 & 0.058 & -0.067
\end{tabular}


1e Grade Secondary

2e Grade Secondary

3e Grade Secondary

North/West/Eastern Europe

Southern Europe

Outside Europe

Skilled worker

Lower civil servant

Intermediate civil servant

Higher civil servant

Fri occupations with academic education

Entrepreneur

Agricultural worker

Single parent family

Mother unemployed

Father unemployed

Gothenburg

Malmoe

Other larger cities

Medium sized cities

Large municipalities

Smaller municipalities

Country site

Share unemployed

Share immigrants

Size manufacturing sector

Right wing populist mandate

Mean grade level

Well being at school

University- and occup. Preparing program

Ocuupational preparing program

Individual program

Restlessness(index)

Aggressiveness(index)

Risk preference(index)

Nervousness(index)

Parent communication(index)

$\begin{array}{lll}-0.052 & -0.086^{*} & -0.020 \\ 0.026 & 0.013 & 0.059 \\ 0.084^{* *} & 0.102^{* *} & 0.107^{* *} \\ 0.100^{* * *} & 0.052 & 0.135^{* * *} \\ 0.159^{* *} & 0.147 & 0.173^{*} \\ 0.178^{* * *} & 0.167 * * * & 0.206^{* * *}\end{array}$

$\begin{array}{lll}0.009 & -0.004 & 0.031\end{array}$

$\begin{array}{lll}0.040 & 0.044 & 0.034\end{array}$

$0.133^{* * *} \quad 0.123^{* * *} \quad 0.136^{* * *}$

$0.162 * * * \quad 0.143 * * * \quad 0.173 * * *$

$0.143 * * * \quad 0.191 * * * \quad 0.098$

$\begin{array}{lll}0.040 & 0.028 & 0.064\end{array}$

$\begin{array}{lll}0.093 & 0.133 & 0.071\end{array}$

$\begin{array}{lll}-0.016 & 0.012 & -0.056^{*}\end{array}$

$\begin{array}{lll}0.032 & -0.006 & 0.053\end{array}$

$\begin{array}{lll}-0.029 & -0.098 & 0.058\end{array}$

$\begin{array}{lll}-0.052 & -0.181^{* *} & 0.172\end{array}$

$\begin{array}{lll}0.245^{* *} & 0.384^{* *} & 0.091\end{array}$

$\begin{array}{lll}0.054 & 0.067 & 0.057\end{array}$

$\begin{array}{lll}-0.016 & 0.024 & 0.031\end{array}$

$\begin{array}{lll}0.049 & 0.084 & 0.049\end{array}$

$\begin{array}{lll}-0.038 & -0.083 & 0.036\end{array}$

$\begin{array}{lll}0.073 & 0.103 & 0.080\end{array}$

$\begin{array}{lll}-0.012 * & -0.007 & -0.019 * *\end{array}$

$-0.005^{* * *} \quad-0.003 * \quad-0.007 * * *$

$-0.004 * * * \quad-0.001 \quad-0.007 * * *$

$-0.178^{* * *} \quad-0.136 * * * \quad-0.204 * * *$

$\begin{array}{lll}0.214 * * * & 0.288^{* * *} \quad 0.135^{* * * *}\end{array}$

$0.099 * * * \quad 0.077 * * * \quad 0.120 * * *$

$\begin{array}{lll}-0.033 & 0.104 & -0.103 *\end{array}$

$-0.186^{* * *} \quad-0.016 \quad-0.346^{* * *}$

$-0.332 * * * \quad-0.338 * * * \quad-0.385 * * *$

$-0.038 * * * \quad-0.047 * * * \quad-0.030 *$

$-0.055^{* * *} \quad-0.038^{* * *} \quad-0.072 * * *$

$\begin{array}{lll}0.012 * & 0.009 & 0.015\end{array}$

$0.070 * * * \quad 0.057 * * * \quad 0.084 * * *$

$\begin{array}{lll}-0.044 * * * & -0.039 * * * & -0.047 * * *\end{array}$

$\begin{array}{llll}\text { Parent knowledge recreational activities(index) } & -0.018 & -0.028 * & -0.008\end{array}$

Parent reaction problematic behaviour(index) $\quad 0.055^{* * *} \quad 0.047^{* * *} \quad 0.058^{* * *}$

Friend relations(index)

Know Muslim

$0.014 \quad 0.038^{*} \quad 0.001$

Does not know Muslim

$0.095 * * * \quad 0.129 * * * \quad 0.073 * * *$

$-0.165 * * * \quad-0.123 * * * \quad-0.203 * * *$

Feelings of exclusion from society (index) $\quad-0.159 * * * \quad-0.160 * * * \quad-0.159 * * *$

Gender roll patterns (index) $\quad-0.347 * * * \quad-0.352 * * * \quad-0.337 * * *$

\begin{tabular}{llll}
\hline Constant & $2.988^{* * *}$ & $2.705^{* * *}$ & $3.262^{* * *}$ \\
\hline Adjusted $R^{2}$ & 0.369 & 0.352 & 0.352 \\
Number & 9498 & 4680 & 4818 \\
\hline
\end{tabular}


$* * *$ signifikant $<0,001, * *$ signifikant $<0,005, *$ signifikant $<0,010$

Demographic factors: When it comes to age/grade the results of the regression for both girls and boys show few differences in effect of age/grade on the attitude towards Muslims. With the exception of those who attend the highest grade of secondary schooling (consequently also age) no significant effect could be measured on the attitude towards Muslims, which is in line with the means shown in the earlier section. However, the regressions for girls and boys separately show that for boys attending the second year of secondary schooling, a significant positive effect is measured. Girls attending the highest level of primary schooling have also a significant positive attitude towards Muslims.

Boys born outside Sweden have a more positive attitude towards Muslims relative to boys born in Sweden. For girls we find that girls born outside of Europe have a more positive attitude towards Muslims than those born in Europe. Moreover, young people who know a person that is a Muslim have a significantly more positive attitude towards Muslims relative to somebody who does not know a Muslim. A possible explanation for these results could be that young people from outside Europe to a larger extent are living in areas and attend schools with more Muslims in them.

Interestingly, the results indicate no difference in attitude towards Muslims between boys and girls. This is different from what was measured in the earlier discussed descriptive section. This result is mainly due to the inclusion of the variable stereotypical gender role ideas in the model.

Socioeconomic factors: While we in the earlier section presented a more stepwise, "the higher, the more positive", connection between attitudes and socioeconomic background, the regressions presented in the table show that only pupils with parents having academic occupations have a more positive attitude towards Muslims. For all other occupations we find no statistically significant effect. Boys living in single parent families have a more negative attitude towards Muslims than those who live with both parents. For girls no significant effect of this variable could be measured. 
Local and regional factors: In earlier reports it is indicated that the more urban environment a person is living in, the more positive one is towards Muslims. As described in an earlier section, this study uses a different geographical division for region of living and find for boys no statistically significant difference in attitude towards Muslims by region of living. For girls however, we find an interesting difference with the cities Gothenburg and Malmoe on one side, and all other regions (including Stockholm), on the other. Girls in Gothenburg have a somewhat less positive attitude towards Muslims, while girls in Malmoe clearly have a clear positive attitude. For the other regions, no statistical significant difference could be measured relative the reference category Stockholm.

However, economic factors at the local level have a certain importance for young peoples' attitudes towards Muslims. Boys who live in municipalities with a relatively larger manufacturing sector, a higher level of unemployment and a higher share of immigrants living in the municipality, have a more negative attitude towards Muslims than boys who live in municipalities with the opposite conditions. One possible explanation for this result could be that a relative larger manufacturing sector exposed for competition is related to larger business cycle variation and fluctuations in unemployment. One interpretation could be that some boys in these municipalities blame this situation on immigration in general and Muslims in particular. For girls we do not find significant results for these variables.

Finally, our categorisation of municipalities into a binary variable wherein either a municipality has right wing populist political seats in local government or not, show that young people that live in municipalities where these parties have seats have more negative attitudes towards Muslims than young people living in municipalities without such seats. A possible explanation could be that the attitude towards Muslims by young people is also affected by other negative attitudes on immigrants and Muslims in the local community.

School factors: School- and program factors are important explanatory factors for the attitude towards Muslims by the pupils. An increased individual grade is correlated with a more positive attitude towards Muslims. Pupils who attend the individual program 
(lowest), have a more negative attitude towards Muslims relative the other secondary programs. In line with earlier studies we also find a strong correlation between the occupational distribution of the parents and school performance of pupils.

Social psychological factors: Social psychological factors like restlessness and aggressiveness also affect the attitude towards Muslims of both girls and boys. This is in line with earlier research that has indicated that so called intolerant youth are more restless. It is most likely that these young people also have negative attitudes towards Muslims. A hypothetical explanation for the result that was found for "increasing nervousness" and increasing positive attitude could be that this is a proxy for emotional sensitiveness and a more nuanced concept of reality, which in turn could lead to an increased tolerance towards those who are perceived as different.

Family factors: In the model also questions where included that measured the effect of degree of confidential communication with parents, parent knowledge about the recreational activities of their child and the reaction of parents on problematic behaviour of their children, on the attitude towards Muslims. According to the analysis, pupils with parents who reacted strongly on their problematic behaviour have a more positive attitude towards Muslims. Surprisingly we found the opposite signs for the other measurements.

Friend factors: If girls have good relationships they have a more positive attitude towards Muslims relative to if they have lees good relationships. This relation was not found for boys. One explanation for this could be that among boys "good relationships" can be related to having company of intolerant groups of friends (Intolerans 2004) which statistically is less likely for girls.

Feelings of exclusion from society: The question on feelings of exclusion from society is based on idea that tolerance against immigrants and minorities varies with the degree of trust to other human beings and is asked with the aim to measure to what extent pupils feel in- or excluded from society on a general level. The analysis shows that this 
variable has a significant effect on the attitude towards Muslims for both boys and girls. The higher the feeling of exclusion, the more the negative attitude is measured.

Gender roll patterns: Finally an index measuring gender roll patterns among pupils is included in the model. The idea behind this inclusion is that the attitude towards Muslims could be influenced by "gender roll ideals" by both girls and boys. The results show that both boys and girls with more stereotypical, inflexible gender roll perceptions have a more negative attitude towards Muslims relative to those who have other perceptions about gender roles.

\section{Summary and discussion}

The Muslim population in Sweden has increased substantially since the 1950s and in particular in the last two decades to approximately 350.000 in 2003 of which one third is of school age or younger. The integration of a new population takes time and this accounts also for immigrants with a Muslim background. However, some immigrant groups show a faster pace of integration than others. At the same time the society needs to adapt to its new demography. Moreover the media climate in Sweden towards Muslims is not particular benevolent. Both in popular culture and textbooks, stereotypes with mainly negative connotations on Muslims and Islam are prevailing. The above and the fact that relatively few studies have been carried out measuring the attitudes towards Muslims in general and of young people in particular, stress the importance of analysing the attitudes towards Muslims by non-Muslim youth in Sweden

Earlier Swedish and international statistical studies on attitudes towards Muslims have included relatively few explanatory variables and used only basic statistical tools to measure variation in attitudes towards Muslims. As a complement to earlier studies this study has with the use of multiple regression technique shown that many variables have a significant, either positive or negative effect on the attitude towards Muslims by young people.

Returning to the earlier studies and the theoretical considerations described in section 2, various propositions in these are supported by the results of the study. In line 
with earlier studies, also here we reveal that individual characteristics have an important influence on the attitude towards others, in this case Muslims. To some extent individual factors like age, country of birth and socioeconomic background, but more social psychological factors like aggressiveness and restlessness, but also perceptions about others, gender in this case, and society at large are important factors explaining attitudes towards Muslims. Interestingly no difference between girls and boys was measured. At the group level, to some extent family factors but also clearly friend factors, especially when a respondent knows a Muslim, have significant effects on the attitude towards Muslims. This result indicates support for the idea that familiarity and increased contact with the other induces more positive attitudes towards others. Economic, political demographic factors at the societal level show in this study having an affect on the attitude towards Muslims, especially for boys. Increased number of immigrants and higher unemployment level can be seen as threats to the status quo and increased competition for scarce resources in the area where one lives and support in this way to these theoretical propositions.

While the immediate reaction might be that these analyses are sufficient when explaining the attitudes of the intolerant, those who propose a structural analysis prefer to make additions to be able to answer questions like why Muslims are targeted. There is a claim that discourses on Islam and Muslims are especially strong and that there is a widespread Islamophobia in society reproduced in for example different kinds of media and popular culture. Why is this not visible in our study, or is it? The previous study on the same statistical material shows that the attitudes to Jews, homosexuals, Immigrants and Muslims are similar, even though marginally harsher against Muslims (Intolerans 2004). In our analysis it is clear that it is the well adjusted children of the well educated and employed who are the most tolerant. Could it be that they also hold a competence for expressing tolerance in questionnaires, thus concealing other forms of othering? According to Olivier Roy (2004) one of the principal misconceptions of Muslims is that Muslims are perceived as a group not a mere population with diverse interests. Muslims are often ethnified, i.e. turned into an ethnic group and ascribed a homogeneous culture. Ètienne Balibar (1997/2002) further claim that a dominating form of new racism is when cultural identity is ascribed to individuals and when group categories are closed, not 
allowing hybridity and transformation. Thus the mere fact that the questionnaire groups Muslims together as "Muslims" helps the middle class to avoid exposing the foundation of their cultural assumptions in line with Balibar's proposed neo-racism. Tolerance against the other is a norm, helping to avoid the difficult question of inclusion and exclusion. This line of reasoning can not be tested with the help of our material but it would be interesting to design questionnaires taking these theoretical ideas into account.

Concluding, our analysis shed some light on what factors seem to be relevant explaining the attitude towards Muslims by young people. Since these results are highly contextual and difficult to generalise to other time and places we are highly careful in stating that the measured effects will last in different environments. Our recommendation is therefore increased future research in this topic, both comparative and longitudinal, that could confirm or refute the results of this study. 


\section{References}

Adorno, T.W., E. Frenkel-Brunswik, D.J. Levinson \& R. Nevitt Sanford, 1950, The authoritarian personality, New York: Norton.

Allport, G.W., 1958, The Nature of Prejudice, Cambridge: Addison Wesley.

Anwar, Muhammad, Jochen Blaschke \& Åke Sander (eds), 2004, State Policies Toward Muslim Minorities: Sweden, Great Britain and Germany. Berlin: Edition Parabolis.

Balibar, Étienne, 1997/2002, "Finns det en 'nyrasism'?” i E. Balibar \& I. Wallerstein, Ras, nation, klass: Mångtydiga identiteter. Göteborg: Daidalos.

Berg, Magnus, 1998, Hudud - Ett resonemang om populärorientalismens bruksvärde och världsbild. Stockholm: Carlson.

Bevelander, Pieter \& Christer Lundh, 2007, 'Employment Integration of Refugees: The influence of Local Factors on Refugee Job Opportunities in Sweden, IZA-Discussion paper No. 2551.

Blalock, H.M., 1967, Toward a Theory of Minority Group Relations, New York: Wiley.

Cattacin, S., B. Gerber, M. Sardo, R. Wegener, 2006. "Monitoring misanthrophy and rightwing extremist attitudes in Switzerland, an explorative study". Research report PNR 40+, Geneva: University of Geneva.

Dustmann, C., F. Fabbri \& I. Preston, 2004, Ethnic Concentration, Prejudice and Racial Harassment Towards Minorities in the UK.

Fredrickson, George M, 2003, Rasism - En historisk översikt. Lund: Historiska media.

Heitmeyer, Wilhelm (red.), 2002, Deutsche Zustände, Folge 1. Frankfurt am Main: Suhrkamp.

Heitmeyer, Wilhelm (red.), 2003, Deutsche Zustände, Folge 2. Frankfurt am Main: Suhrkamp.

Heitmeyer, Wilhelm (red.), 2005, Deutsche Zustände, Folge 3. Frankfurt am Main: Suhrkamp.

Heitmeyer, Wilhelm \& Andreas Zick, 2004, "Anti-Semitism, Islamophobia and Groupfocused Enmity in Germany." Research note at Institute for Interdisciplinary Research on conflict and Violence, University of Bielefeld. 
Hvitfelt, Håkan, 1991, "Svenska attityder till islam" i S. Holmber \& L. Weibull (red.) Politiska opinioner, SOM-undersökningen 1990. SOM-rapport 6, Göteborgs universitet.

Hvitfelt, Håkan, 1998, ”Den muslimska faran - om mediabilden av islam” i Y. Brune (red.) Mörk magi i vita medier - svensk nyhetsjournalistik om invandrare, flyktingar och rasism. Stockholm: Carlssons.

Härenstam, Kjell 1993, Skolboks-islam: Analys av bilden av islam i läroböcker $i$ religionskunskap. Göteborg: Acta Universitatis Gothoburgensis.

Integrationsbarometer 2004: En rapport om allmänhetens inställning till integration, mångfald och diskriminering 2003 och 2004, 2005. Integrationsverkets skriftserie V. Norrköping: Integrationsverket.

Integrationsbarometer 2005: En rapport om allmänhetens attityder, erfarenheter och kunskaper inom områdena integration, mångfald och diskriminering, 2006. Integrationsverkets rapportserie 2006:05. Norrköping: Integrationsverket.

Intolerans - Antisemitiska, homofobiska, islamofobiska och invandrarfientliga tendenser bland unga, 2004, Forum för Levande Historia och Brottsförebyggande Rådet, Stockholm.

Lagerlöf, David, 2006, ”Bland judiska konspiratörer och muslimska kolonisatörer antisemitism och islamofobi på nätet” i Rasism och främlingsfientlighet i Sverige Antisemitism och islamofobi 2005. Integrationsverkets rapportserie 2006:02. Norrköping: Integrationsverket.

Lange, Anders, 2001, 'Reflektioner kring 'rasifiering' och några andra ord” i

Törnrosalandet - om tillhörighet och utanförskap. Norrköping: Integrationsverket. Muslimer och islam i svenska nyhetsmedier - Om rapporteringen av terrorattackerna $i$ USA den 11 september 2001, 2002. Integrationsverkets skriftserie III. Norrköping: Integrationsverket.

Otterbeck, Jonas \& Pieter Bevelander, 2006, Islamofobi - en studie av begreppet, ungdomars attityder och unga muslimer utsatthet, Stockholm: Forum för Levande Historia.

Otterbeck, Jonas, 2006, "Vad kan man egentligen begära? - Läromedelstexter om islam" i P. B. Andersen, C. Dahlgren, S. Johannessen, J. Otterbeck (red.) Religion, skole og 
kulturel integration i Danmark og Sverige. Köpenhamn: Museum Tusculanums Forlag.

Robinson, Julie, Ritvka Witenberg \& Ann Sanson (2001) "The Socialization of Tolerance" in M. Augoustinos (ed.) Understanding Prejudice, racism, and Social Conflict. London: Sage.

Samtal med svenska muslimer - Situationen för svenska muslimer efter terroristattacken $i$ USA den 11 september 2001, 2003. Integrationsverkets rapportserie 2003:3. Norrköping: Integrationsverket.

Sander, Åke \& Göran Larsson, under tryckning, "Discussion of the Definition of Islamophobia" $\mathrm{i}$ The situation of Muslim Communities in the EU-Manifestations of Islamophobia. Vienna: EUMC.

Sherif, M. 1966, Group conflict and co-operation: their social psychology, London: Routledge and Paul Kegan.

Solomos, John \& Les Back, 1999, Theories of Race \& Racism: Reader. Florence, KY, USA: Routledge.

Taifel, Henri, 1982, "Social identity of intergroup relations", Annual Review of Psychology, no. 1.

Åslund, O. \& Rooth D-O., 2005, "Shifts in attitudes and labor market discrimination: Swedish experiences after 9-11", Journal of Population Economics, 18:603-629. 


\section{Appendix I}

\section{Adolescent attitudes towards young Muslims (Mean), girls and boys}

\begin{tabular}{lll}
\hline Statement & Girls & Boys \\
\hline Most Muslims are decent people... & 3,00 & 2,68 \\
It would be entirely okay to have a steady Muslim as a neighbour... & 3,57 & 3,28 \\
Muslims in Sweden should have the right to build Mosques ... & 2,56 & 2,24 \\
There are far too many Muslims in Sweden... & 2,54 & 2,12 \\
You can not trust a Muslim... & 3,02 & 2,69 \\
It should be forbidden for Muslims to vote in elections... & 3,37 & 3,08 \\
Most immigrated Muslims are very likely law-abiding... & 2,67 & 2,38 \\
Most Muslims only want to live on social security... & 2,41 & 2,03 \\
\hline
\end{tabular}

Adolescent attitudes towards young Muslims (Mean), primary and secondary education

\begin{tabular}{llllll}
\hline Statement & 8th & 9th & 1th & 2th & 3th \\
\hline Most Muslims are decent people... & 2,81 & 2,83 & 2,82 & 2,87 & 2,90 \\
It would be entirely okay to have a steady Muslim as a neighbour... & 3,35 & 3,41 & 3,42 & 3,48 & 3,54 \\
Muslims in Sweden should have the right to build Mosques ... & 2,40 & 2,41 & 2,28 & 2,44 & 2,53 \\
There are far too many Muslims in Sweden... & 2,39 & 2,30 & 2,24 & 2,35 & 2,40 \\
You can not trust a Muslim... & 2,78 & 2,87 & 2,83 & 2,81 & 2,95 \\
It should be forbidden for Muslims to vote in elections... & 3,15 & 3,17 & 3,22 & 3,33 & 2,36 \\
Most immigrated Muslims are very likely law-abiding... & 2,54 & 2,56 & 2,54 & 2,61 & 2,70 \\
Most Muslims only want to live on social security... & 2,14 & 2,14 & 2,20 & 2,32 & 2,43 \\
\hline
\end{tabular}

Adolescent attitudes towards young Muslims (Mean), region of birth

\begin{tabular}{|c|c|c|c|c|}
\hline Statement & Sweden & $\begin{array}{l}\text { North/West/Eastern } \\
\text { Europe }\end{array}$ & $\begin{array}{l}\text { Southern } \\
\text { Europe }\end{array}$ & $\begin{array}{l}\text { Outside } \\
\text { Europe }\end{array}$ \\
\hline Most Muslims are decent people... & 2,84 & 2,88 & 2,90 & 2,79 \\
\hline $\begin{array}{l}\text { It would be entirely okay to have a } \\
\text { steady Muslim as a neighbour... }\end{array}$ & 3,41 & 3,48 & 3,58 & 3,45 \\
\hline $\begin{array}{l}\text { Muslims in Sweden should have the } \\
\text { right to build Mosques ... }\end{array}$ & 2,34 & 2,44 & 2,50 & 2,68 \\
\hline $\begin{array}{l}\text { There are far too many Muslims in } \\
\text { Sweden... }\end{array}$ & 2,33 & 2,33 & 2,27 & 2,37 \\
\hline You can not trust a Muslim... & 2,84 & 2,90 & 2,89 & 2,92 \\
\hline $\begin{array}{l}\text { It should be forbidden for Muslims to } \\
\text { vote in elections... }\end{array}$ & 3,19 & 3,24 & 3,49 & 3,51 \\
\hline $\begin{array}{l}\text { Most immigrated Muslims are very } \\
\text { likely law-abiding... }\end{array}$ & 2,57 & 2,56 & 2,59 & 2,73 \\
\hline $\begin{array}{l}\text { Most Muslims only want to live on } \\
\text { social security... }\end{array}$ & 2,22 & 2,20 & 2,14 & 2,31 \\
\hline
\end{tabular}




\section{Appendix II}

\section{Independent variables}

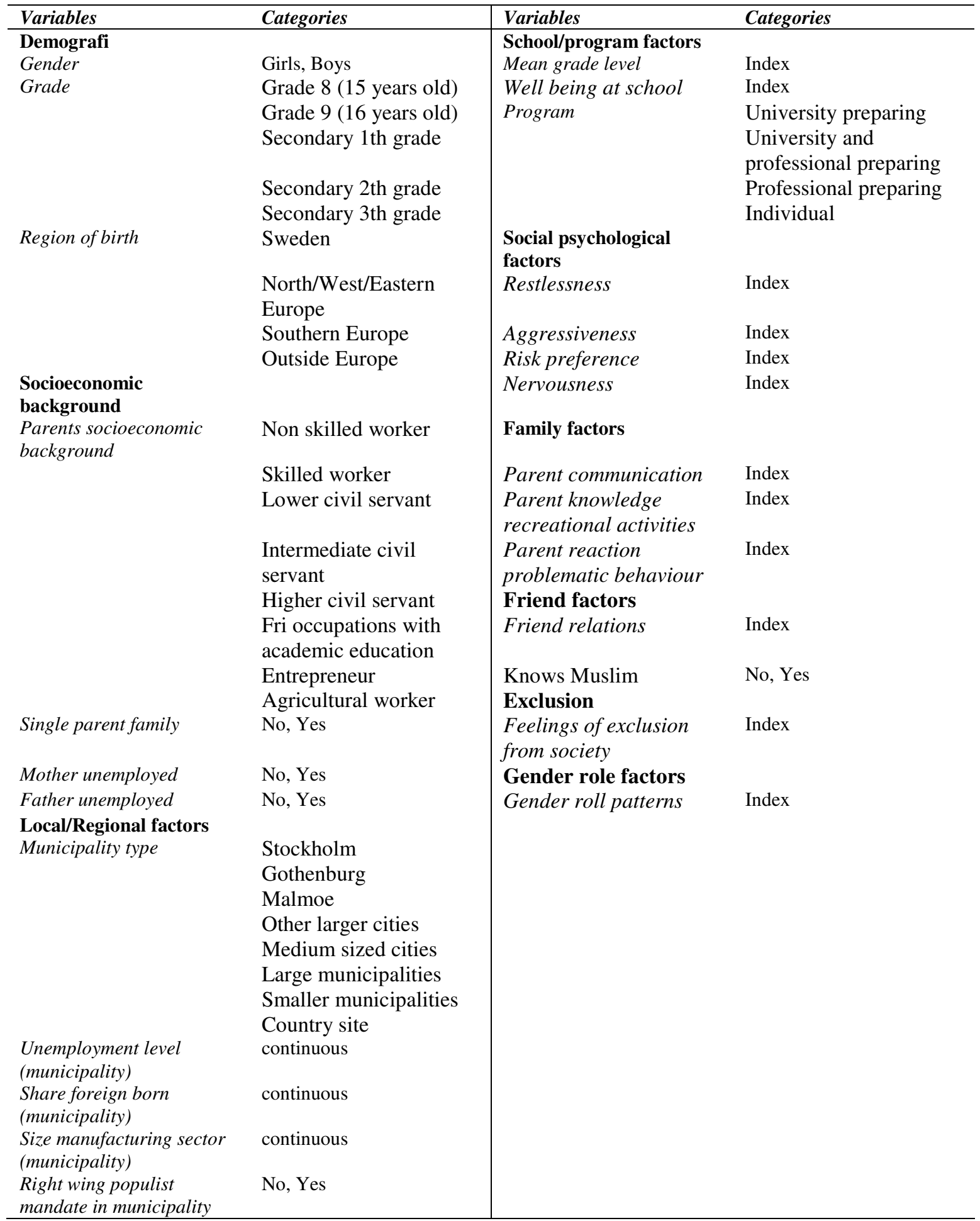

\section{Appendix III}




\section{Municipality types}

\begin{tabular}{|l|l|l|}
\hline Municipality type & Population & Definition \\
\hline Stockholm & 527 & $>200.000$ \\
\hline Gothenburg & 366 & $>200.000$ \\
\hline Malmoe & 96 & $>200.000$ \\
\hline Other larger cities & 3546 & $50.000-200.000$ \\
\hline Medium sized cities & 2774 & $20.000-50.000$ \\
\hline Large municipalities & 1268 & $10.000-20.000$ \\
\hline Smaller municipalities & 407 & $<10.000$ inv. \\
\hline Country site & 694 & $<7$ indiviuals per km \\
\hline
\end{tabular}




\section{Appendix IV}

\section{Overview of questions included in the various indexes}

\begin{tabular}{|c|c|c|}
\hline Index & Questions & Answering alternative \\
\hline \multirow[t]{5}{*}{ Restlessness } & $\begin{array}{l}\text { Finally here come some questions about } \\
\text { yourself. Cross if the following statements } \\
\text { are correct with how you are! }\end{array}$ & \multirow{5}{*}{$\begin{array}{l}5 \text { answering alternatives: yes, this is } \\
\text { correct; this is relatively correct; } \\
\text { unsure/doesn't know; this is rather } \\
\text { incorrect; no, this is incorrect }\end{array}$} \\
\hline & $\begin{array}{l}\text { I have often thought that it is difficult to sit } \\
\text { still a longer period, for example a lecture. } \\
\text { If I am forced to wait a while on for } \\
\text { example a buss I will easily get extreme } \\
\text { restless. }\end{array}$ & \\
\hline & $\begin{array}{l}\text { I will get uninterested if not is happening } \\
\text { new all the time. }\end{array}$ & \\
\hline & $\begin{array}{l}\text { It happens often that I do things impulsively } \\
\text { without thinking so carefully. }\end{array}$ & \\
\hline & $\begin{array}{l}\text { Sometimes I do something unexpected and } \\
\text { crazy without planning.. }\end{array}$ & \\
\hline Aggressiveness & $\begin{array}{l}\text { I get easily angry. } \\
\text { I feel often anger inside me. }\end{array}$ & $\begin{array}{l}5 \text { answering alternatives: yes, this is } \\
\text { correct; this is relatively correct; } \\
\text { unsure/doesn't know; this is rather } \\
\text { incorrect; no, this is incorrect }\end{array}$ \\
\hline \multirow[t]{2}{*}{ Risk preference: } & $\begin{array}{l}\text { Sometimes it is fun to take some risk just } \\
\text { for the sake of excitement. } \\
\text { I like to test climbing even if this can be } \\
\text { risky. }\end{array}$ & \multirow[t]{3}{*}{$\begin{array}{l}5 \text { answering alternatives: yes, this is } \\
\text { correct; this is relatively correct; } \\
\text { unsure/doesn't know; this is rather } \\
\text { incorrect; no, this is incorrect }\end{array}$} \\
\hline & $\begin{array}{l}\text { I absolutely would like to test to jump } \\
\text { "bungy jump". }\end{array}$ & \\
\hline \multirow[t]{3}{*}{ Nervousness } & $\begin{array}{l}\text { The following questions deal with how you } \\
\text { felt the last couple of months. Mark the best } \\
\text { alternative that fits with you! }\end{array}$ & \\
\hline & I have felt myself depressive and down. & \multirow[t]{3}{*}{$\begin{array}{l}4 \text { answering alternatives: no, not at all to } \\
\text { often }\end{array}$} \\
\hline & I felt myself troubled. & \\
\hline \multirow[t]{5}{*}{ Mean grade level } & $\begin{array}{l}\text { I have had difficulties to sleep. } \\
\text { What had you for grade last term in the } \\
\text { following subjects? }\end{array}$ & \\
\hline & Mathematics & \multirow[t]{3}{*}{$\begin{array}{l}4 \text { answering alternatives: not pass, pass, } \\
\text { high pass and very high pass }\end{array}$} \\
\hline & Swedish & \\
\hline & English & \\
\hline & Chemistry/Natural Science & \\
\hline
\end{tabular}


Well being at school:

\author{
Parent \\ communication:
}

Parent knowledge recreational activities:

\section{Parent reaction problematic behavior:}

\section{Gender roll patterns:}

Feelings of exclusion from society:
Mark if the following statements about school fit or fit not for you!

I usually feel very comfortable in school.

I like to do my home work properly.

I like most of the teachers.

Cross how you think that the following

statements fit for you!

I can usually talk about everything with mamma (for example problems)

I can usually talk about everything with daddy (for example problems)

My parents usually know where I am if I go out in the evening/night.

My parents usually know who I meet if I go out in the evening/night.

If I would shirk from school and my parents say this they would be angry and disappointed.

If I would come home drunk on a Friday evening my parents would be discontented.

Do you think it suitable or not for boys and girls respectively to show the following different types of feelings, behavior and characteristics?

A real boy has to be cool and strong and a real girl has above all to be pretty.

A girl that does not use make-up is actually not pretty.

It is more suitable for a girl to cry than for a boy.

A real boy should fight for his honour otherwise he is not worth any respect.

A girl who has been together with many boys is not worth respect.

A boy who is scared for mice and spiders is actually a real softy.

Now some questions that deal with your future and some other things. Mark for the followingt statement that best suites your opinion or feeling!
5 answering alternatives: yes, this is correct; this is relatively correct; unsure/doesn't know; this is rather incorrect; no, this is incorrect

5 answering alternatives: yes, this is correct; this is relatively correct; unsure/doesn't know; this is rather incorrect; no, this is incorrect

5 answering alternatives: yes, this is correct; this is relatively correct; unsure/doesn't know; this is rather incorrect; no, this is incorrect

5 answering alternatives: yes, this is correct; this is relatively correct; unsure/doesn't know; this is rather incorrect; no, this is incorrect

5 answering alternatives: yes, this is correct; this is relatively correct; unsure/doesn't know; this is rather incorrect; no, this is incorrect 
Most politicians do not really bother in the problems of ordinary people.

Those who decide think in the first place on their own interests.

I think the future is unsure and I prefer not to think about it.

In these days it is difficult to know who one can trust.

A lot is so complicated in today's society that it is easy to be confused.

To be successful in society one is almost enforced to do some things illegally

Friend relations:

Mark for the following statements about friends and if they fit with you or not!

I can talk about everything with the friends (problems) I most of all meet...

My friends help me willingly if I need help with something...

My fiends mean actually a lot to me...

I really respect the opinions of my friends...

I feel often disappointed of my friends...
5 answering alternatives: yes, this is correct; this is relatively correct; unsure/doesn't know; this is rather incorrect; no, this is incorrect

5 answering alternatives: yes, this is correct; this is relatively correct; unsure/doesn't know; this is rather incorrect; no, this is incorrect 